\title{
Ayurvedic Management on Vicharchika- A case study
}

\author{
Dr. Viraj Kelkar'1, Dr. Renu Raokhande ${ }^{2}$ \\ ${ }^{1}$ Assistant Professor, Agadtantra Department, YMT Ayurvedic Medical College, Kharghar, Navi Mumbai. \\ ${ }^{2}$ Associate Professor, Bhargava Ayurvedic Medical College, Dahemi, Anand, Gujarat.
}

\begin{abstract}
Vicharchika is often correlated to eczema based on the clinical presentation. Eczema is a form of dermatitis. As per Ayurvedic texts Vicharchika is characterized by symptoms namely kandu (itching), srava (discharge), pidaka (vesicles) and shyava vrana (discolouration). No satisfactory treatment is available in contemporary medical practice except antihistamines and topical steroids. A 55 years old female patient approached to OPD with chief complains of discharge, edema, erythematous skin lesion and intense itching at right ankle region. Line of treatment plan was Raktamokshana as shodhana upkarma and Shaman aushadhi according to dosh dushya samurchana. Remarkable improvement was observed within span of 30 days of commencement of treatment.
\end{abstract}

KEY WORDS: Vicharchika, Raktamokshana, Eczema

\section{INTRODUCTION}

All Kushthas are having Tridoshaja origin; hence Vicharchika can be explained in similar manner. These are the kind of non-contagious inflammation of the skin characterized by erythema, Scaling, edema, vesiculation and oozing the disease Vicharchika to a greater extent resembles eczema/dermatitis. Therefore the eczematous dermatitis can be included in study of Vicharchika. Vicharchika can be correlated with eczema in the sequence. (1) In classical texts of Ayurveda, Acharyas emphasizes Shodhana and Shamana therapy as the line of treatment at various places. Among the Shodhana Karmas, The texts of Ayurveda consider Rakta Dusti as one of the prime causes of skin diseases (2). On the other hand, patients may get relief after letting out the vitiated Rakta. Acharya Sushruta propounds practical guidelines for bloodletting and claims it as most effective therapy in half of the body ailments [3]. Among various methods for bloodletting[4] such as Prachhanna Karma,[5] and Siravedhana Karma.[4] Jalaukaavacharna Karma[] (Leech therapy) is considered as the ideal method to expel out the vitiated blood safely, quickly, and effectively. Siravedhana Karma (Vein puncture) is routinely practiced in the past and so much importance is given to it in classics. So, Jalaukavacharana and Siravedhana Karma were considered to evaluate their comparative efficacy in cases of Vicharchika (Eczema). Vicharchika can be treated with Shodhana Chikitsa and Shamana Chikitsa(7). Here, a female subject, aged 55 years with the chief complains of discharge, edema, erythematous skin lesion and intense itching at right ankle region.

\section{CASE REPORT}

A 55-year-old female presented with the complains of discharge, edema, erythematous skin lesion and intense itching at right ankle region since 3 years. The patient also complained of oozing from non-healing wound present of Right ankle region. (Approximately $4 \times 3 \mathrm{~cm}$ ) associated with burning sensation, since 3 
${ }^{1}$ Dr. Viraj Kelkar, International Journal of Ayurvedic\& Herbal Medicine 11(6) Nov.-Dec. 2021 (4029-4033)

years. Routine haematology ( $\mathrm{Hb}, \mathrm{TC}, \mathrm{DC}, \mathrm{ESR})$ and urine investigations were within normal limits. The skin lesion was sent for culture and sensitivity test and report showed no growth. Patient treated with two sessions of Jalukavacharana in $2^{\text {nd }}$ week and $4^{\text {th }}$ week.

Table 1. Shows Shodhan treatment done.

\begin{tabular}{|l|l|l|}
\hline Sr. no. & Panchakarma therapy & On Site \\
\hline 1. & Jalukavacharana & At right foot ankle joint region (In $2^{\text {nd }}$ week and $4^{\text {th }}$ week once) \\
\hline
\end{tabular}

Table 2. Shows Shaman chikitsa done.

\begin{tabular}{|l|l|l|l|l|}
\hline Sr. No. & FORMULATIOS & DOSE & DURATION & ANUPANA \\
\hline 1. & Ghandhak Rasayan & $250 \mathrm{mg}$ & 2 BD (after meal) & Luke warm water \\
\hline 2. & Bilvadi Gutika & $250 \mathrm{mg}$ & 2BD (after meal) & Luke warm water \\
\hline 3. & Mahatikta Ghruta & Half tsp & Twice a day ( before meal) & Luke warm water \\
\hline 4. & Aragvadh Kashay & $15 \mathrm{ml}$ & Twice a day(before meal) & Luke warm water \\
\hline
\end{tabular}

OBSERVATION

\section{A.OBJECTIVE PARAMETERS ${ }^{(8)}$}
1) Scaling
2) Extent of lesions
3) Circular skin lesion
4) Thickening and elevation of skin lesion.

Table 3. B. OBJECTIVE PARAMETERS (9)

\begin{tabular}{|c|c|c|c|}
\hline $\begin{array}{l}\text { Sr. } \\
\text { No }\end{array}$ & $\begin{array}{l}\text { Subjective } \\
\text { Symtoms }\end{array}$ & Parameters & Gradation \\
\hline 1. & Kandu(Itching) & $\begin{array}{l}\text { No Itching } \\
\text { Relive Spontaneously } \\
\text { Relive by Itching } \\
\text { Disturb routine } \\
\text { Require Medication }\end{array}$ & $\begin{array}{l}+1 \\
+2 \\
+3 \\
+4\end{array}$ \\
\hline 2. & $\begin{array}{l}\text { Vaivarnya } \\
\text { (Discoloration) }\end{array}$ & $\begin{array}{l}\text { Normal } \text { Colour } \\
\text { Light Brown } \\
\text { Brick Brown } \\
\text { Dark Brown } \\
\text { Black Brown }\end{array}$ & $\begin{array}{l}0 \\
+1 \\
+2 \\
+3 \\
+4\end{array}$ \\
\hline 3. & Sravva (Discharge) & $\begin{array}{l}\text { No Discharge } \\
\text { Occasionally discharge } \\
\text { Discharge on Itching } \\
\text { Relieve Spontaneously } \\
\text { Not at all Relieve }\end{array}$ & $\begin{array}{l}+1 \\
+2 \\
+3 \\
+4\end{array}$ \\
\hline 4. & Rukshata (Dryness) & $\begin{array}{l}\text { No scratch after scratching } \\
\text { Mild scratch after scratching } \\
\text { Scaling on every scratch } \\
\text { Scratching causes eruption } \\
\text { Spontaneous eruption on scratching of skin }\end{array}$ & $\begin{array}{l}0 \\
+1 \\
+2 \\
+3 \\
+4\end{array}$ \\
\hline
\end{tabular}


${ }^{1}$ Dr. Viraj Kelkar, International Journal of Ayurvedic\& Herbal Medicine 11(6) Nov.-Dec. 2021 (4029-4033) BEFORE TREATMENT

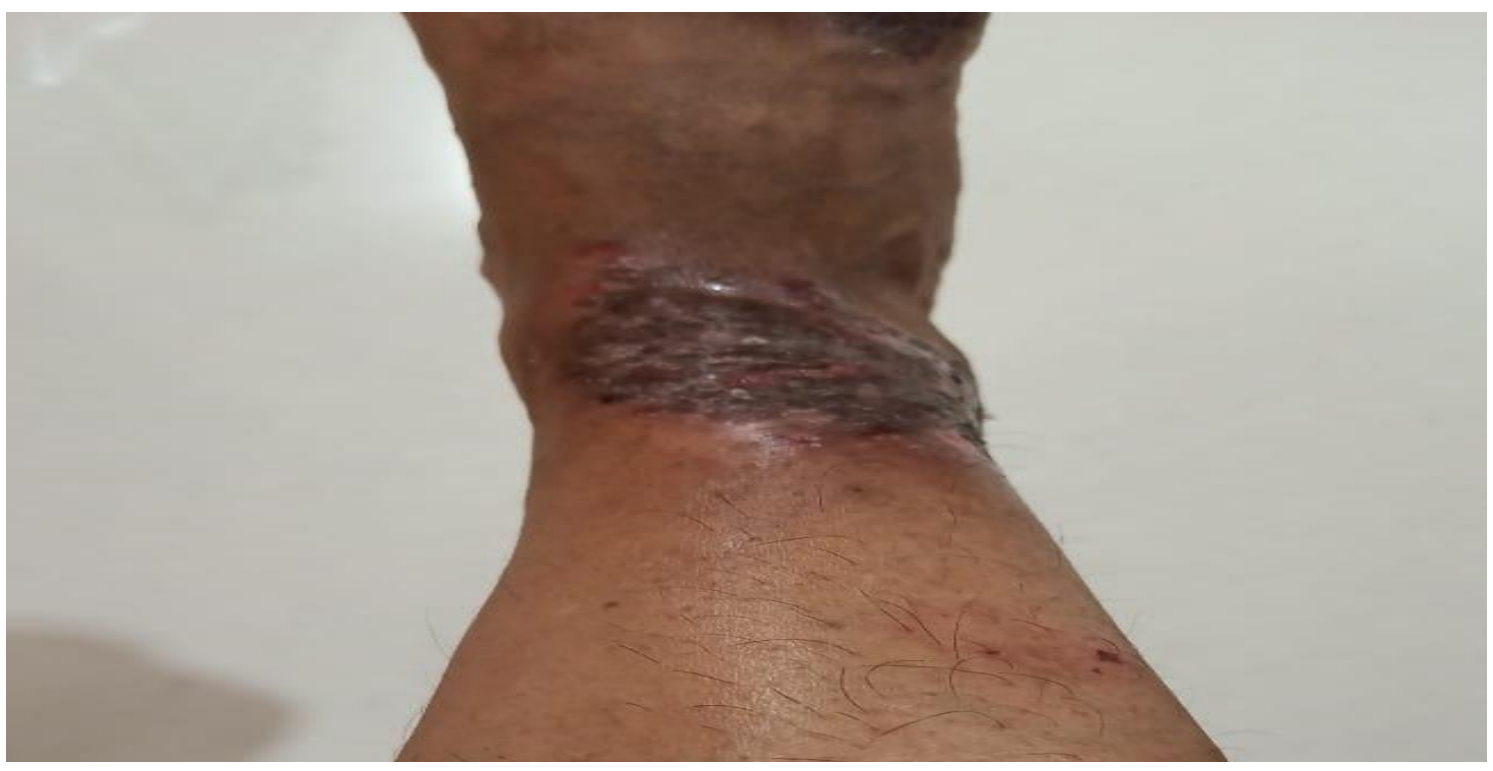

\section{AFTER TREATMENT}

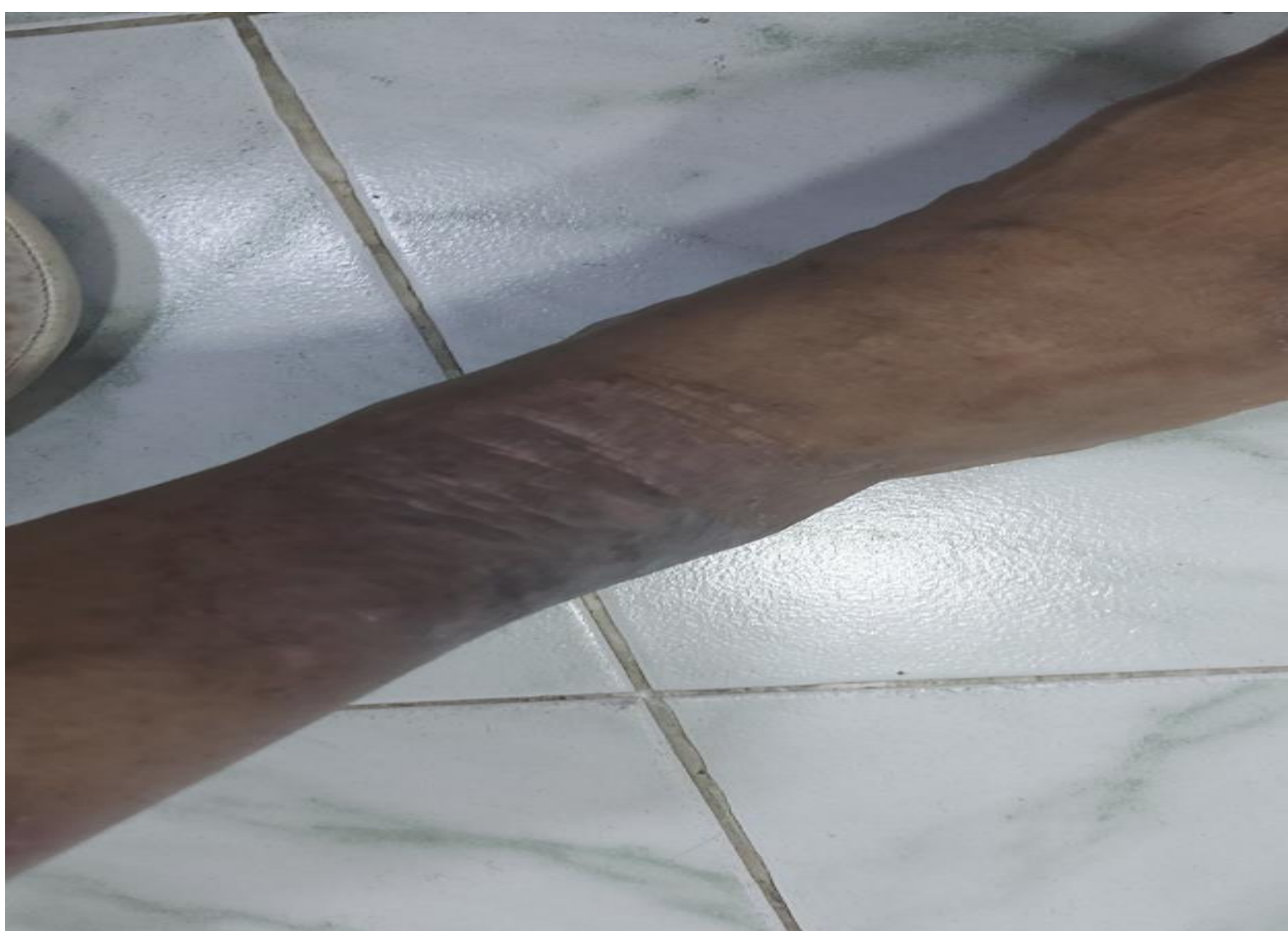

Table 4. RESULT

\begin{tabular}{|c|l|l|l|l|}
\hline Sr. no & Symptoms & $\begin{array}{l}\text { Before } \\
\text { Treatment }\end{array}$ & $\begin{array}{l}\text { After } \\
\text { Treatment }\end{array}$ & \% of relief \\
\hline 1 & Kandu (Itching) & 4 & 0 & $100 \%$ \\
\hline 2 & $\begin{array}{l}\text { Vaivarnya } \\
\text { (discolouration) }\end{array}$ & 4 & 1 & $75 \%$ \\
\hline 3 & Srava (Discharge) & 2 & 0 & $100 \%$ \\
\hline 4 & Dryness & 2 & 0 & $100 \%$ \\
\hline
\end{tabular}




\section{DISCUSSION}

In this case study Ayurvedic line of management gives satisfactory answer as well, the treatment was planned according to vitiated Dosha, affected Dushya and Sroto Dushti. Panchakarma therapies are the processes of well-planned cleaning \& detoxification of the body. It also boost the immune system hence provide subjective and objective relief to the patient. Panchakarma enhances this natural process. In addition to this if internal medication is administered after Shodhana process like Jalukavacharana etc.

Tridosha vitiation is responsible for Vicharchika. The symptom Kandu is may be due to expelling out of vitiated morbid Dosha (toxins) from local region. Leech salivary secretions also provide early healing effect by secondary haemorrhage which might have reduced itch impulse. Kandu (itching) and Strava was relieved. Leeches are antiphlogistic, used for the local obstruction of the blood. Congested blood is also removed from the local area by leech; so, better relief in strava might have been provided by Jalaukavacharana.

Vaivarnya (discoloration) was removed. Jalauka removes impure blood and allows oxygenated blood to enter the wound area, which might have provided better color to skin.

Shotha (Edema) was relieved due to reduction of local pressure by substance like eglins and bdellins present in leech saliva. Leech saliva contains anaesthetic substance which helps in pain relive. (10)

\section{Ghandhak Rasayan}

Ghandhak Rasayan is a Ayurvedic Formulation having anti-bacterial, anti-microbial, antiinflammatory activity. It is effective remedy for all skin diseases.

\section{Bilvadi Gutika}

Bilwadi Gutika contents Bilwa swarasa, Karanja, Tagar, Devdaru, Triphala, Daruharidra etc which accordingly having antimicrobial, antiviral property. It does aam pachana, helps to improve gara visha and agni mandya.

\section{Mahatikta Ghruta}

Mahatikta ghruta comproses of Katuki, aragvadha,pippali, turmeric, yashtimadhu, nrihalphala,guduchi, kirattikta,neem,vasaka,shatavari and various other drugs. It has blood purifying, anti-infective and restorative properties that helps in eliminating ama from the body and balancing the vitiated doshas. It is useful in the management of skin diseases like eczema, dermatitis, leprosy and urticarial.

\section{Aragvadhadi Kashaya}

The ingredient of Aragvadhadi Kashaya is aragvadh, indrayava,nimba,murva, patha, bhunimba, chitraka etc. which mainly work on kapha-pitta hara. It also have property like neutralises all kind of visha, useful in all kind of shin diseases, eleminites kaphaja symptoms like itching, reduces strava, heals all kind of dusta vrana.

\section{CONCLUSION}

In above case study patient got relief from symptoms of Vicharchika. We got good result by using Shodhana and Shamana chikitsa for the periods of four weeks In this case Jalukavacharana helps to remove sthanik dosha from blood and bring samyavastha of doshas. By same time shaman chikitsa gives excellent result on lesion- scar, discharge and amavastha. Ghandhak rasayan, Aragvadhadi Kashaya helps to improve blood purification and maintain skin complexion as well. Present observation and approach endorses a step toward the practice of Ayurvedic intervention in Vicharchika (Eczema). Present case definitely boosts up the new researcher scholar to take this condition and do the further studies.

\section{Patient perspective}

Patient was satisfied to get complete remission. 
${ }^{1}$ Dr. Viraj Kelkar, International Journal of Ayurvedic\& Herbal Medicine 11(6) Nov.-Dec. 2021 (4029-4033)

\section{REFERENCE}

1. https://www.journalcra.com/article/study-vicharchika-corelation-eczema

2. Aacharya Vaidya Jadavaji Trikamji., editor. Vol. 24. Varanasi: Chaukhamba Sanskrit Sansthan; 1990. Charaka, Charakasamhita, Sutrasthana, Vidhishonitiya Adhyaya; p. 12. [Google Scholar]

3. Aacharya Vaidya Jadavaji Trikamji, Acharya Narayana Ram., editors. 2nd ed. Vol. 8. Varanasi: Chaukhamba Surbharti Prakashan; 1990. Susruta, Susrutasamhita, Sutrasthana, Shastravacharniya Adhyaya; p. 23. [Google Scholar]

4. Ibidem Susruta Samhita. Sutra Sthana Jalaukavacharniya Adhyaya. 13:4. [Google Scholar]

5. Ibidem Susruta Samhita. Sutra Sthana Jalaukavacharniya Adhyaya. 13:40. [Google Scholar]

6. Ibidem Susruta Samhita. Sutra Sthana Shonitavarnaniya Adhyaya. 14:24. [Google Scholar]

7. https://www.ncbi.nlm.nih.gov/pmc/articles/PMC3456867/

8. Anuradha Vijay Bhalerao, and Jyoti V. Meghadambar, AYURVEDIC MANAGEMENT OF PSORIASIS: A CASE STUDY, Int. Res. J.Pharma, 2018; 9(6): 225.

9. Anuradha Vijay Bhalerao, and Jyoti V. Meghadambar, AYURVEDIC MANAGEMENT OF PSORIASIS: A CASE STUDY, Int. Res. J. Pharma, 2018; 9(6): 225.

10. Farming Medicinal Leeches. [Last updated on 2010 Feb 16; cited on 2002 Aug 05]. Available from: http://www. leeches.biz/ 